\title{
Hubungan Faktor Lingkungan Dengan Kejadian Demam Berdarah Dengue di Kabupaten Maros Sulawesi Selatan
}

\author{
Musdalifah Syamsul \\ Akademi Keperawatan Al-Hambra Makassar, Sulawesi Selatan, Indonesia \\ iffahullaina@gmail.com
}

\begin{abstract}
(C) 2018 - UEJ Program Studi Pendidikan Kependudukan dan Lingkungan Hidup
Universitas Negeri Makassar. Ini adalah artikel dengan akses terbuka dibawah Licensi CC BY-NC-4.0 (http:/creativecommons.org/licenses/by-nc/4.0)
\end{abstract}

\begin{abstract}
.
Penyakit demam berdarah dengue (DBD) merupakan salah satu masalah kesehatan masyarakat di Indonesia dan sering menimbulkan kejadian luar biasa dengan jumlah kematian yang besar. Di Kabupaten Maros merupakan daerah endemis demam berdarah dan meningkatnya kejadian demam berdarah dengue dipengaruhi oleh banyak faktor, salah satunya adalah faktor lingkungan seperti sarana air bersih dan saluran air hujan. Tujuan penelitian ini adalah untuk mengetahui gambaran faktor lingkungan dengan kejadian demam berdarah di Kabupaten Maros tahun 2013-2017. Penelitian ini menggunakan pendekatan kualitatif deskriptif. Subjek utama penelitian ini adalah petugas kesehatan dinas kesehatan dan Puskesmas. Pengumpulan data dengan indepth interview dan data sekunder. Hasil penelitian dapat disimpulkan bahwa faktor lingkungan berupa sarana air bersih, dan saluran air hujan yang menjadi tempat perindukan nyamuk Aedes dan sebagian besar informan menyatakan bahwa sarana air bersih dan saluran air hujan merupakan faktor yang sangat berperan terhadap penularan ataupun terjadinya kejadian luar biasa DBD. Saran penelitian ini hendaknya pemerintah kabupaten Maros mempertimbangkan program pencegahan dan penanggulangan demam berdarah dengue bekerjasama dengan dinas kesehatan, dan masyarakat ikut serta dalam pencegahan dan penanggulangan demam berdarah dengue dengan melaksanakan $3 M$ khususnya pada musim hujan.
\end{abstract}

Keywords: faktor lingkungan, penyakit, demam berdarah dengue

\section{PENDAHULUAN}

Tujuan pembangunan Nasional di bidang kesehatan adalah meningkatkan kesadaran, kemauan dan kemampuan hidup sehat bagi setiap orang agar terwujud derajat kesehatan masyarakat. Menurut World Health Organization (WHO) tahun 1948 menyebutkan bahwa Sehat adalah sebagai "suatu keadaan fisik, mental,sosial kesejahteraan dan bukan hanya ketiadaan penyakit atau kelemahan". Pembangunan kesehatan merupakan upaya untuk memenuhi salah satu hak dasar masyarakat yaitu hak untuk memperoleh pelayanan kesehatan sesuai dengan Undang undang Dasar1945 khususnya Pasal 28 $\mathrm{H}$ ayat 1dan Undang Undang No 36 Tahun 2009 tentang Kesehatan dan Pasal 71 ayat 2 dan 3 yang membahas mengenai kesehatan reproduksi termasuk dilaksanakan melalui kegiatan promotive preventif, kuratif, dan rehabilitatif

Penyakit Demam Berdarah Dengue (DBD) merupakan salah satu masalah kesehatan masyarakat penting di Indonesia dan sering menimbulkan suatu letusan Kejadian Luar Biasa (KLB) dengan kematian yang besar. Di Indonesia nyamuk penular (vektor) penyakit DBD yang penting adalah Aedes aegypti, Aedes albopictus, dan Aedes Scutellaris, tetapi sampai saat ini yang menjadi vektor utama dari penyakit DBD adalah Aedes aegypti. Penyakit DBD pertama kali ditemukan pada tahun 1968 di Surabaya dengan kasus 58 orang anak, 24 diantaranya meninggal dengan Case Fatality Rate (CFR) = $41,3 \%$. Sejak itu penyakit DBD menunjukkan kecenderungan peningkatan jumlah kasus dan luas daerah terjangkit. Seluruh wilayah Indonesia mempunyai resiko untuk terjangkit penyakit DBD, kecuali daerah yang memiliki ketinggian lebih dari 1000 meter di atas permukaan laut (Kemenkes, 2013).

Penyakit DBD dipengaruhi oleh kondisi lingkungan, mobilitas penduduk, kepadatan penduduk, adanya kontainer buatan ataupun alami di tempat pembuangan akhir sampah (TPA) ataupun di tempat sampah lainnya, penyuluhan dan perilaku masyarakat, antara lain: pengetahuan, sikap, kegiatan pemberantasan sarang nyamuk (PSN), fogging, abatisasi, dan pelaksanaan 3M (menguras, menutup, dan 
mengubur). Tempat potensial untuk perindukan nyamuk Aedes aegypti adalah tempat Penampungan Air (TPA) yang digunakan sehari-hari, yaitu drum, bak mandi, bak WC, gentong, ember dan lain-lain. Tempat perindukan lainnya yang non TPA adalah vas bunga, ban bekas, botol bekas, tempat minum burung, tempat sampah dan lain-lain, serta TPA alamiah, yaitu lubang pohon, daun pisang, pelepah daun keladi, lubang batu, dan lain-lain. Adanya kontainer di tempat ibadah, pasar dan saluran air hujan yang tidak lancar di sekitar rumah juga merupakan tempat perkembangbiakan yang baik (Soegijanto, 2004).

Beberapa faktor yang beresiko terjadinya penularan dan semakin berkembangnya penyakit DBD adalah pertumbuhan jumlah penduduk yang tidak memiliki pola tertentu, faktor urbanisasi yang tidak berencana dan terkontrol dengan baik, semakin majunya sistem transportasi sehingga mobilisasi penduduk sangat mudah, system pengelolaan limbah dan penyediaan air bersih yang tidak memadai, berkembangnya penyebaran dan kepadatan nyamuk, kurangnya system pengendalian nyamuk yang efektif, serta melemahnya struktur kesehatan masyarakat. Selain faktor lingkungan tersebut diatas, status imunologi seseorang juga sangat berpengaruh, virus yang menginfeksi, usia, dan riwayat genetic juga berpengaruh terhadap penularan penyakit (Kemenkes, 2013).

Berdasarkan data yang didapat, kabupaten Maros merupakan salah satu daerah yang rawan terjangkit penyakit demam berdarah dengue, hal ini dapat dilihat dari angka kejadian kasus demam berdarah dengue yang terjadi dari tahun ke tahun. Pada tahun 2013 jumlah kasus kejadian 245 kasus dengan 3 angka kematian ( $I R=73.84$ dan $C F R=1.22)$, tahun 2014 jumlah kasus kejadian 449 kasus dengan 2 angka kematian ( $I R=133.79$ dan $C F R=0.45), 2015$ jumlah kasus kejadian 397 kasus dengan 1 angka kematian $(\mathrm{IR}=117.01$ dan $\mathrm{CFR}=0.25), 2016$ jumlah kasus kejadian 628 kasus dengan 1 angka kematian ( $I R=183.15$ dan CFR=0.16), Januari - September 2017 jumlah kasus kejadian 180 kasus dengan 2 angka kematian ( $I R=52.49$ dan $C F R=1.11$ ) (Dinas Kesehatan Kab. Maros, 2017).

Tingginya angka kesakitan demam berdarah dengue di Kabupaten Maros ini disebabkan karena adanya kondisi lingkungan yang buruk, seperti saluran pembuangan air limbah yang tersumbat, sarana pembuangan sampah yang belum memadai, banyaknya genangan air di jalan yang merupakan sarana perkembangbiakan nyamuk aedes agypti yang cukup potensial. Selain itu juga didukung dengan tidak maksimalnya kegiatan Pemberantasan Sarang Nyamuk di masyarakat sehingga menimbulkan kasus penyakit demam berdarah di beberapa wilayah di Kabupaten Maros (Profil Kesehatan Maros, 2016). Melihat data tersebut dapat diartikan bahwa pada tahun berikutnya dimungkinkan terjadi lonjakan kasus demam berdarah dengue. Untuk menanggulangi lonjakan kasus DBD perlu ada intervensi pada daerahdaerah endemis DBD sehingga tidak terjadi KLB DBD, yakni perlu memperhatikan aspek lingkungan dan kesadaran masyarakat sebagai upaya untuk menurunkan angka kejadian kasus DBD.

\section{METODE}

Jenis penelitian ini menggunakan metode penelitian kualitatif yang prosedur penelitiannya menghasilkan data deskriptif berupa kata-kata tertulis atau lisan dari orang-orang dan perilaku yang diamati dan memberikan gambaran distribusi angka kejadian demam berdarah dengue serta gambaran dari faktor lingkungan. Tujuan penelitian kualitatif adalah mengembangkan konsep yang membantu memahami fenomena social dalam lingkungan yang alami. Metode penelitian kualitatif digunakan karena beberapa pertimbangan yakni (1) menyesuaikan metode kualitatif lebih mudah apabila berhadapan dengan kenyataan jamak, (2) metode ini menyajikan secara langsung hakikat hubungan antara peneliti dan responden, (3) metode ini lebih peka dan lebih dapat menyesuaikan diri dengan banyak penajaman pengaruh bersama terhadap pola-pola nilai yang dihadapi (Notoatmojo, 2012).

\section{HASIL DAN PEMBAHASAN}

Lingkungan merupakan salah satu faktor yang mempengaruhi derajat kesehatan masyarakat. Nyamuk Aides agypti umunya memiliki habitat di lingkungan perumahan, di mana terdapat banyak genangan air bersih dalam bak mandi ataupun tempayan. Nyamuk Aedes aegypti, meletakkan telur pada permukaan air bersih secara individual. Telur berbentuk elips berwarna hitam dan terpisah satu dengan yang lain. Telur menetas dalam 1 sampai 2 hari menjadi larva. Terdapat empat tahapan dalam perkembangan larva yang disebut instar. Perkembangan dari instar 1 ke instar 4 memerlukan waktu sekitar 5 hari. Setelah mencapai instar ke-4, larva berubah menjadi pupa di mana larva memasuki masa 
dorman. Pupa bertahan selama 2 hari sebelum akhirnya nyamuk dewasa keluar dari pupa. Perkembangan dari telur hingga nyamuk dewasa membutuhkan waktu 7 hingga 8 hari, namun dapat lebih lama jika kondisi lingkungan tidak mendukung (Kemenkes, 2013).

Air bersih dan sanitasi yang baik merupakan elemen penting yang menunjang kesehatan manusia. Sanitasi berhubungan dengan kesehatan lingkungan yang mempengaruhi derajat kesehatan masyarakat. Sarana air bersih yang dimiliki oleh masyarakat di kabupaten Maros menunjukkan pada tahun 2013 sebesar 40,77\%, tahun 2014 sebesar 43,45\%, tahun 2015 sebesar 56,45\%, dan 49,24\% pada tahun 2016. Dengan keadaan lingkungan yang sangat memungkinkan berkembang biaknya nyamuk maka hal ini sangat berpengaruh, apalagi dengan kondisi sumber air bersih yang masih sangat kurang aman atau memiliki tutup yang membuat nyamuk dapat berkembang biak di dalam tempat tersebut. Nyamuk Aedes aegypti memilih lokasi perkembangbiakan di air yang bersih dan tidak terkontaminasi oleh tanah sehingga sumber-sumber air bersih yang terdapat di sekitar lingkungan rumah dijadikan saasaran yang baik untuk Nyamuk Aides aegypti berkembang biak. Sarana air bersih yang tidak memenuhi persyaratan beresiko menjadi tempat berkembang biaknya vector pembawa penyakit di dalam penelitian ini khususnya nyamuk Aedes Aegypt yang pada dasarnya hanya bisa berkembang biak di air yang bersih sehingga sarana air bersih yang kurang diperhatikan oleh pemilik menjadi sasaran untuk berkembang biak yang sangat baik oleh nyamuk (Profil Kesehatan Kab Maros, 2016).

Hal ini serupa dengan hasil penelitian yang dilakukan oleh Yuniati dengan judul Pengaruh sanitasi lingkungan pemukiman terhadap kejadian demam berdarah Dengue (DBD) di daerah aliran sungai deli kota pada tahun 2012. Pada penelitian yang dilakukan oleh Anastasia Pramudyawardhani (2012) Hubungan faktor lingkungan dan perilaku masyarakat dengan kejadian DBD di wilayah kerja Puskesmas Klaten Utara Kab Klaten, didapatkan hasil bahwa faktor lingkungan berhubungan dengan kejadian DBD, sedangkan perilaku masyarakat yang berhubungan dengan kejadian DBD yaitu kebiasaan menggantung pakaian, menguras tempat penampungan air, membuang sampah dan menggunakan anti nyamuk.

Perubahan musim dari kemarau ke penghujan menjadi titik rawan ledakan kasus demam berdarah, apalagi didukung oleh keberadaan saluran air hujan yang dapat menampung genangan air. Kegiatan gotong royong untuk membersihkan lingkungan terutama saluran got menjadi mutlak dilakukan. Upaya ini dapat menekan populasi nyamuk DBD pada saat musim puncak, sehingga wabah atau kejadian luar biasa penyakit DBD dapat dihindari. Hasil penelitian menunjukkan bahwa keberadaan saluran air hujan di kabupaten Maros, menunjukkan tahun 2013 sebesar 60,12\%, tahun 2014 sebesar 45,17\%, tahun 2015 sebesar 53,40\%, tahun 2016 sebesar 56,03\%. Keberadaan saluran air hujan dengan keberadaan vektor DBD sangat mempengaruhi. Hasil penelitian ini didukung oleh hasil penelitian Arman (2005) yang menunjukkan adanya hubungan antara keberadaan saluran air hujan dengan endemisitas demam berdarah dengue.

Hasil penelitian sesuai dengan pernyataan Soegijanto (2004) yang menyebutkan bahwa telur, larva, dan pupa nyamuk Aedes aegypti tumbuh dan berkembang di dalam air. Genangan yang disukai sebagai tempat perindukkan nyamuk ini berupa genangan air yang tertampung di suatu wadah yang biasa disebut tempat penampungan air bukan genangan air di tanah. Kegiatan gotong royong untuk membersihkan lingkungan terutama saluran got menjadi mutlak dilakukan. Upaya ini dapat menekan populasi nyamuk DBD pada saat musim puncak, sehingga wabah atau kejadian luar biasa penyakit DBD dapat dihindari.

\section{KESIMPULAN}

Dari hasil pengumpulan data penelitian disimpulkan bahwa faktor lingkungan berupa sarana air bersih, dan saluran air hujan yang berada di luar rumah menjadi tempat perindukan nyamuk Aedes sebagai vektor penyakit Demam Berdarah Dengue, dan merupakan faktor yang sangat berperan terhadap penularan ataupun terjadinya kejadian luar biasa penyakit Demam Berdarah Dengue di Kabupaten Maros. Diharapkan bagi masyarakat yang mempunyai tempat perindukan nyamuk seperti sarana air bersih dan saluran air hujan untuk selalu melakukan kegiatan 3M Plus dan pemberantasan sarang nyamuk secara rutin. Bagi instansi kesehatan diharapkan lebih meningkatkan tindakan promotif dan preventif kepada masyarakat untuk mengatasi masalah DBD. Pemerintah kabupaten Maros, hendaknya mempertimbangkan program pencegahan dan penanggulangan demam berdarah dengue bekerjasama dengan dinas kesehatan 
UNM Environmental Journals, Vol.1 No.3 Agustus 2018 hal. $82-85$

\section{REFERENSI}

Arman, E.P. 2005. Faktor Lingkungan dan Perilaku Kesehatan yang Berhubungan dengan Endemisitas Demam Berdarah Dengue. Surabaya

Dinas Kesehatan Kabupaten Maros. 2014. Profil Kesehatan Kabupaten Maros 2013. Sub. Bagian Perencanaan dan Pelaporan Dinas Kesehatan Kabupaten Maros Tahun

Dinas Kesehatan Kabupaten Maros. 2015. Profil Kesehatan Kabupaten Maros 2014. Sub. Bagian Perencanaan dan Pelaporan Dinas Kesehatan Kabupaten Maros

Dinas Kesehatan Kabupaten Maros. 2016. Profil Kesehatan Kabupaten Maros 2015. Sub. Bagian Perencanaan dan Pelaporan Dinas Kesehatan Kabupaten Maros Tahun

Dinas Kesehatan Kabupaten Maros. 2017. Profil Kesehatan Kabupaten Maros 2016. Sub. Bagian Perencanaan dan Pelaporan Dinas Kesehatan Kabupaten Maros Tahun

Notoatmojo, S. 2012. Metode Penelitian Kesehatan, Jakarta. Rhineka Cipta.

Soegijanto, S. 2004. Demam Berdarah Dengue. Surabaya: Airlangga University Press

Pramudyawardhani. Anastasia. 2012. Hubungan Factor Lingkungan dan Perilaku Masyarakat dengan Kejadian DBD di Wilayah Kerja Puskesmas Klaten Utara Kab Klaten. Klaten.

Yuniati, 2012. Pengaruh Sanitasi Lingkungan Pemukiman terhadap Kejadian Demam Berdarah Dengue (DBD) di Daerah Aliran Sungai Deli Kota pada Tahun 2012.

Kementrian Kesehatan Republik Indonesia. 2013. Pedoman Penanggulangan Demam Berdarah Dengue di Indonesia. Kemenkes

Kementrian Kesehatan Republik Indonesia. 2013. Petunjuk Teknis Pemberantasan Sarang Nyamuk Demam Berdarah Dengue oleh Juru Pemantik (Jumantik). Kemenkes 